\title{
Genetic Diversity of Rhizobia Nodulating Alfalfa in Iraq as a Source of More Efficient Drought Tolerance Strains
}

\author{
Rana Azeez Hameed ${ }^{1}$, Nidhal Neema Hussain ${ }^{2}$ \& Abd aljasim Muhisen Aljibouri ${ }^{3}$ \\ ${ }^{1}$ Biology Department, Al-Mustansiriyah University, Baghdad, Iraq \\ ${ }^{2}$ Biology Department, Baghdad University, Baghdad, Iraq \\ ${ }^{3}$ Plant Biotechnology Department, Biotechnology Research Center, Al-Nahrain University, Baghdad, Iraq \\ Correspondence: Rana Azeez Hameed, Biology Department, Al-Mustansiriyah University, Baghdad, Iraq. Tel: \\ 964-770-926-3030.E-mail: alroomir@yahoo.com
}

Received: March 3, $2016 \quad$ Accepted: March 18, $2016 \quad$ Online Published: March 29, 2016
doi:10.5539/jmbr.v6n1p20 $\quad$ URL: http://dx.doi.org/10.5539/jmbr.v6n1p20

\begin{abstract}
Sinorhizobium meliloti is a gram-negative, soil bacteria, which gain a huge importance deserved to their capability in fixing nitrogen symbiotically with an important fodder crop legume-alfalfa (Medicago sativa). This study aims to (i): isolate indigenous Sinorhizobium meliloti from different field sites in Iraq; (ii): assess the isolates tolerance to induced water shortage using polyethylene glycol-6000; (iii): evaluate genetic diversity and genetic relationships among isolates of natural population with drought tolerant abilities. Drought tolerance analysis disclose great variations between Sinorhizobium isolates, the highest tolerant isolates to drought were 12 from whole thirty (40\%), endured from -3 up to $-4 \mathrm{MPa}(\mathrm{Mega}$ pascal), at the same time the drought sensitive isolates tolerated up to $-1.5 \mathrm{MPa}$, but for isolate Bs58 which tolerated up to $-1 \mathrm{MPa}$. The growth decrease with the increase of drought stress. REP-PCR method was an excellent technique to distinguish between the $S$. isolates based on their tolerance to different water potential levels, the REP-PCR gave a significant band about 700bp (base pair) in size, which were present in all drought moderate and tolerant isolates, while this band was absent in all drought sensitive isolates(except one isolate). Also the ERIC-PCR method cleared the absence of two significant bands $300 \mathrm{bp}$ and $600 \mathrm{bp}$ from all drought sensitive isolates. UPGMA analysis based on rep-PCR revealed two groups branching at a similarity of $35 \%$, first group included only one isolate Bs 16 , which was a drought moderate tolerant; second group contained the rest of isolates, yet the latter splits into two subgroups with $68 \%$ similarity; the first subgroup comprised all sensitive isolates with $80 \%$ similarity among them, the second subgroup included the tolerant and moderate isolates with similarity $88 \%$.
\end{abstract}

Keywords: REP-PCR, ERIC-PCR, Sinorhizobium, drought

\section{Introduction}

Iraq is placed in arid and semi-arid regions of the world, were annual rainfall is less than $200 \mathrm{~mm}$, and so it goes under severe shortage of irrigation water (Tara, 2011). The effect of environment change on biota has currently gained attention. Furthermore, dry lands cover $40 \%$ of the world land surface of living. Desertification influence $70 \%$ of the world dry lands (Roy, Mazumder, \& Sarma, 2009) Fabaceae family plants are often used for cultivation in degraded soil sites of arid and semi-arid regions as they can grow in dry soils that are unsuitable for most crops (Pereira, Lima, \& Figueira, 2008). Alfalfa (Medicago sativa L.) is a deep-rooted, perennial plant belong to Fabaceae family, which is capable to utilize atmospheric nitrogen $\left(\mathrm{N}_{2}\right)$ and accumulate significant amounts of $\mathrm{N}_{2}$ in the soil through growth (Zeng, Chen, Hu, Su, \& Chen, 2007). Rhizobia is a beneficial soil bacteria that had a great agricultural value in enhance soil fertility in farming systems (Zahran, 1999). Sinorhizobium meliloti is able to interact with the roots of Medicago to form nitrogen-fixing nodules (Elboutahiri, Hami Alami \&Udupa, 2010). One of the important strategy to improve the yield of arid legumes in pressurized environments should embrace a combination of stress-tolerant cultivars and stress-tolerant Rhizobia (Turner, Wright, \& Siddique, 2001). Distinct phenotypic and genotypic techniques were used to classify and distinguish bacteria, although phenotypic methods are more authenticated reliable for identification and to examine genetic diversity of bacterial isolates (Gao, Terefework, Chen, \& Lindstorm, 2001). 
A great number of molecular methods based on polymerase chain reaction have been designed to characterize Sinorhizobium strains and to provide a high degree of divergence among the closely related bacterial strains. rep PCR technique has been increasingly used to assess genetic variation of microorganisms. Entrobacteria contain families of short interspersed repetitive elements; this includes the Repetitive Extragenic Palindromic element (REP), the Entrobacterial Repetitive Intergeneric Conensus (ERIC) sequence, and the BOX elements, the role of these elements is still uncovered, yet it has been suggested that they may involve in stabilizing mRNA and binding of DNA polymerase. The REP and ERIC sequences contain a highly conserved inverted repeats, and are normally found in inter-genic regions that are transcribed, but not translated (Versalovic, Schneider, De-Bruijn \&Lupski, 1994). The REP-PCR generated genomic fingerprints can be obtained not only from purified genomic DNA, but also directly from rhizobial cells derived from liquid cultures or from colonies on plates as well as from nodule tissue (De-Bruijn, 1992).

\section{Materials and Methods}

Sinorhizobium bacteria were isolated from Alfalfa nodules (Medicago sativa) plants sampled from different geographical sites in Iraq, bacteria were extracted and cultured according to Vincent (1970) procedure. The symbiotic ability of isolates were checked by PIT (Plant Infection Test) (Vincent, 1970). Thirty isolates were tested for growing on CR (CongoRed), Bromothymol blue incorporated with MS (Mannitol Salt Yeast extracted) agar media and gram stain test.

\subsection{Drought Tolerance}

Isolates were tested for drought tolerance by using polyethylene glycol-6000(PEG-6000 w/v) in MSY broth media at different ranges of osmotic pressure from -0.1 to $-4 \mathrm{MPa}$ (mega pascal), plus the control treatment(no PEG-6000)., cultures were incubated at $28 \pm 2^{\circ} \mathrm{C}$ on a rotary shaker in dark conditions for about seven days, then assessed growth.

\subsection{DNA Extraction}

The extraction of genomic DNA was done by following the protocol of wizard genomic DNA purification kit (Promega). The concentration and purity of DNA were estimated with a spectrophotometer.

\section{3 rep - PCR Conditions}

Amplification of DNA fragments of the selected isolates was carried out using the complementary primers to repetitive sequences in the bacterial genome:

\section{REP1: IIIICGICGICATCIGGC}

\section{REP2: ICGICTTATCIGGCCTAC}

The following thermal profiles of the reactions were used:

Initial denaturation $5 \mathrm{~min}, 94^{\circ} \mathrm{C}$

$\left.\begin{array}{ll}\text { Denaturation } & 40 \mathrm{sec}, 94^{\circ} \mathrm{C} \ldots \ldots \ldots \ldots \\ \text { Annealing } & 1 \mathrm{~min}, 59^{\circ} \mathrm{C} \\ \text { Extension } & 1 \mathrm{~min}, 72{ }^{\circ} \mathrm{C} \ldots \ldots \ldots \ldots . . . . .\end{array}\right\} \quad 32 \mathrm{cycle}$

ERIC1: ATGTAAGCTCCTGGGGATTCAC

\section{ERIC2: AAGTAAGTGACTGGGGTGAGCG}

The thermal profile was:

Initial denaturation $4 \mathrm{~min}, 94^{\circ} \mathrm{C}$

Denaturation

$1 \mathrm{~min}, 94^{\circ} \mathrm{C}$

Annealing

$1 \mathrm{~min}, 56^{\circ} \mathrm{C}$

32 cycle

Extension

$2 \min , 72^{\circ} \mathrm{C}$

Final extension

$10 \mathrm{~min}, 72^{\circ} \mathrm{C}$

\subsection{Statistical Analysis}

Comparison of physiological trait was preformed quantitavelly on the basis of growth + or no growth - for each isolate. As for PCR fingerprinting patterns were converted into a two-dimensional binary matrix (1, presence of a 
band, 0, absence of a band) and analyzed using the statistics software package (version 1.92; Past software, Ohammer, 2009) for eleven isolates of Sinorhizobia meliloti.

\section{Results and Discussion}

Studies of different researches illustrated that drought stress is considered one of the major environmental factors affecting almost most crops and casing reduction of crop yield, the population of soil bacteria decreases along the moisture stress (Hossein \& Leila 2010). According to Bremer and Kramer (2000), there are two types of stress responses in microorganisms: the general stress response and specific stress response. The general stress response in normally controlled by a single or a few master regulators, which provide protection against a wide variety of environmental cues and allow cell to survive, yet it may not be enough to let the cell to grow under severe stress conditions. While under prolonged stress conditions cells employ specific stress response which utilize highly integrated networks of genetic and physiological adaptation mechanisms, and this was agreed with results conducted in this research, hence there was a great variation between the isolates, and all isolates grow well on media with induced water potential ranging from -0.1 to $-1.0 \mathrm{MPa}$, while at $-2.5 \mathrm{MPa}$ the growth declined to only $50 \%$ reaching to $6.6 \%$ growth percent at $-4.0 \mathrm{MPa}$ water potential (Figure 1). Also Zahran (1999) reported that in osmotic stress a specific protein formed which was detected as new protein band in sodium dodecyl sulfate polyacrylamide gel electrophoresis profile of rhizobia.

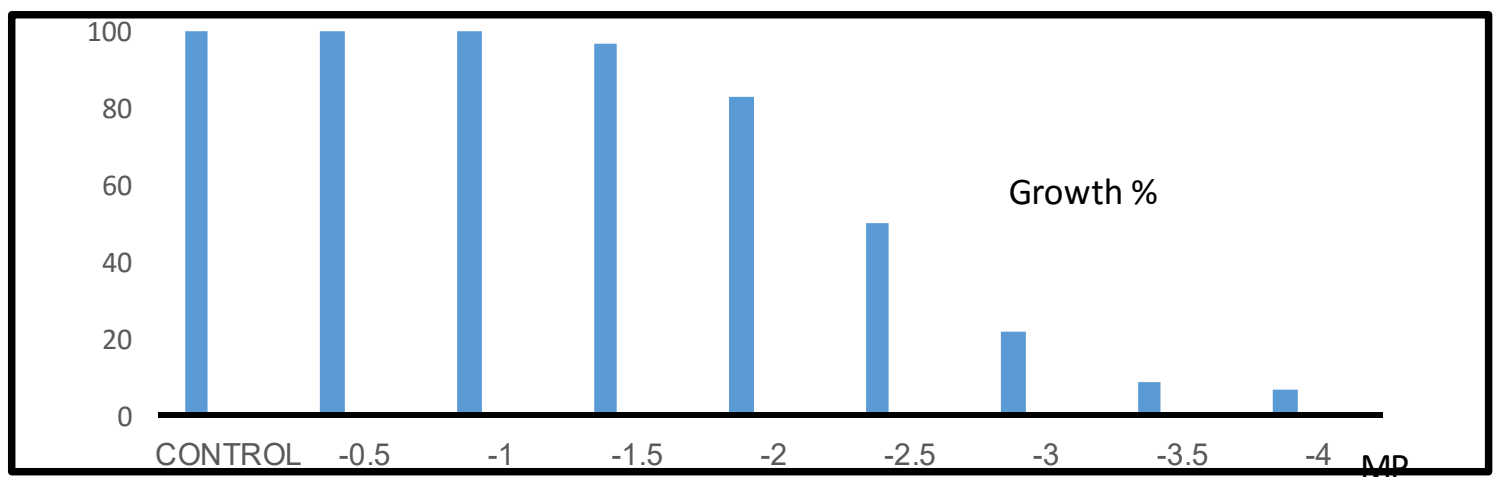

Figure 1. Effect of different water potential levels (MPa) on growth percent of Sinrhizobium isolates

Several reports are now accessible indicating the utility of PCR for fingerprinting of many organisms including soil proteobacteria such as rhizobia (Metha, R. Metha \& Rosato., 2006); Raja, Balachandar and Sundaram (2008). REP-PCR genomic fingerprinting employ DNA primers complementary to naturally occurring and highly conserved repetitive DNA sequences, present in multiple copies in the genome of most of the Gram positive and Gram negative bacteria (Raja et al., 2008).

The Rep-PCR analysis was done using primer set REP1 and REP2 (Versalovic et al., 1994) these primers were used to amplify the repetitive sequences that present in multiple copies in gram negative bacteria genome like Sinorhizobium isolates consequence in (Figure 2) indicate a significant diversity between the drought sensitive and drought tolerant isolates, with the presence of $700 \mathrm{bp}$ size in all drought moderate and tolerant isolates, plus Bs 58(drought sensitive isolate), while this $700 \mathrm{bp}$ band was absent in the other three drought sensitive isolates.

The amplification generated a bands ranged in size about 0.3 to $1.8 \mathrm{~kb}$. The majority of these bands were found in the range of 1.3 to approximately $1.8 \mathrm{~kb}$, the rep-PCR technique generated highly specific, reproducible patterns that allow close strain differentiation, and corresponds with Sikora \& Redzepovic (2003); Elboutahiri et al. (2010); Lisek, Paszt, Oskiera, Kulisiewicz and Malusa (2011).

The ERIC-PCR amplification was originally carried out using the primers set ERIC1 and ERIC2. The amplification generated a bands ranged about 0.3 to $1.3 \mathrm{~kb}$ (estimated using the DNA molecular weight marker as standard), the results demonstrated the absence of two significant bands(300 and $600 \mathrm{bp}$ size each) from all the drought sensitive isolates, Figure 3. 


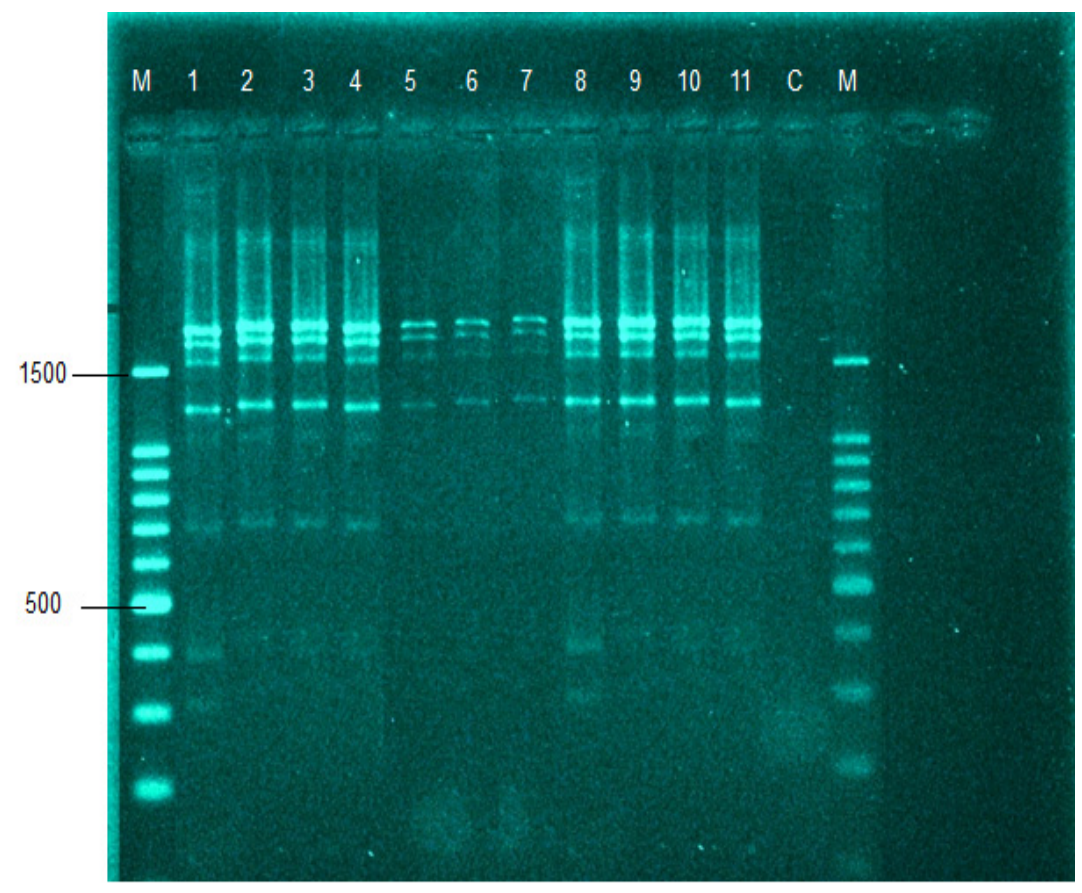

Figure 2. REP-PCR fingerprints of Sinorhizobium meliloti isolates generated by primers set REP1 and REP2. $\mathrm{M}=1 \mathrm{~kb}$ DNA ladder $; 1=\mathrm{Bs} 12 ; 2=\mathrm{Bs} 30 ; 3=\mathrm{Bs} 38 ; 4=\mathrm{Bs} 41 ; 5=\mathrm{Bs} 44 ; 6=\mathrm{Bs} 54 ; 7=\mathrm{Bs} 55 ; 8=\mathrm{Bs} 58 ; 9=\mathrm{Bs} 49 ; 10=\mathrm{Bs}$ $31 ; 11=\mathrm{Bs} 16 ; \mathrm{C}=$ negative control and $\mathrm{M}=1 \mathrm{~kb}$ DNA ladder

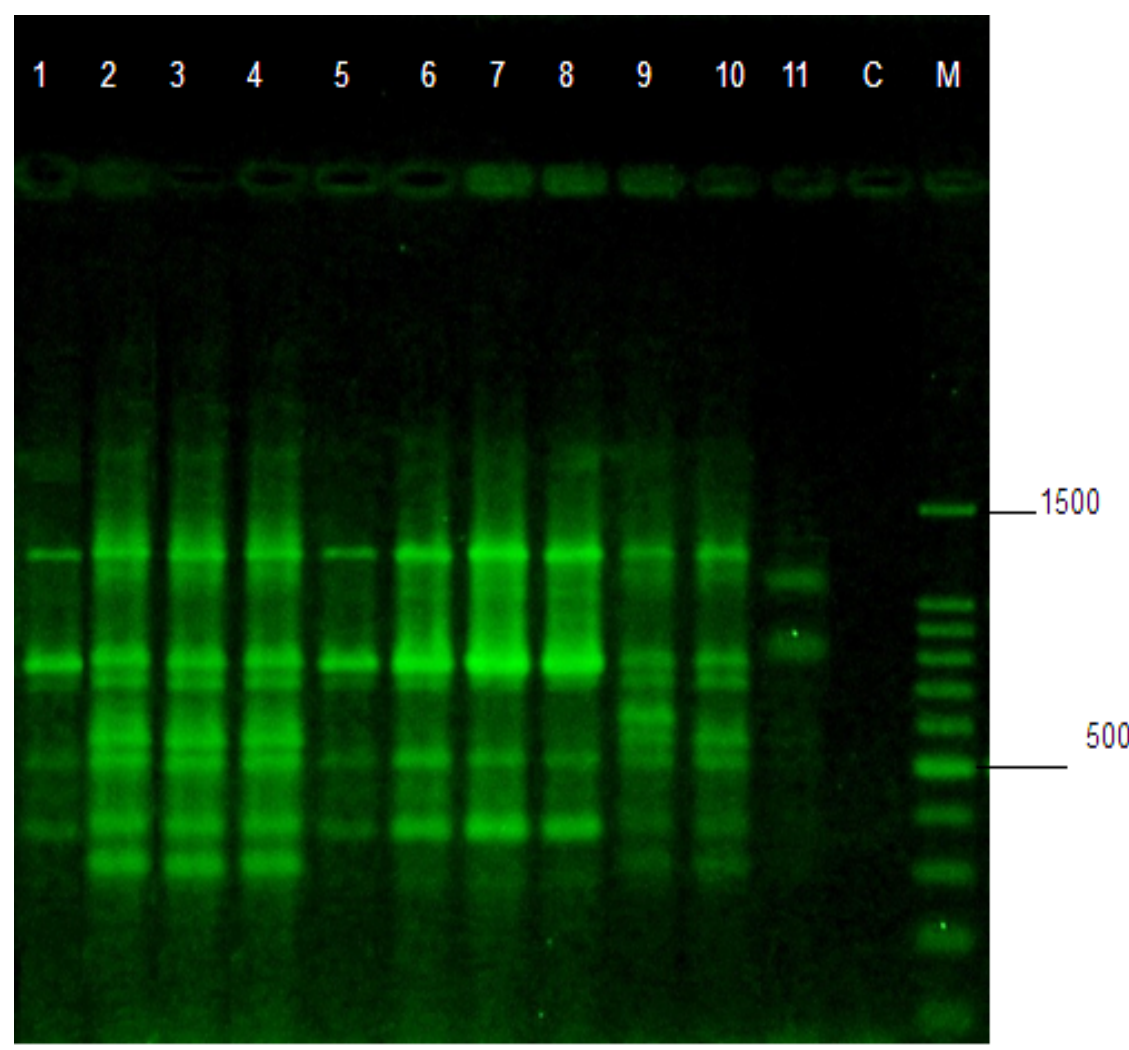

Figure 3. ERIC-PCR fingerprints of Sinorhizobium meliloti isolates generated by primers set ERIC1 and ERIC2.1=Bs 12; $2=$ Bs $30 ; 3=$ Bs $38 ; 4=$ Bs $41 ; 5=$ Bs $44 ; 6=$ Bs $54 ; 7=$ Bs $55 ; 8=$ Bs $58 ; 9=$ Bs $49 ; 10=$ Bs $31 ; 11=$ Bs $16 ; \mathrm{C}=$ negative control and $\mathrm{M}=1 \mathrm{~kb}$ DNA ladder 
The dendrogram in figure 4 showed the genetic similarities between Sinorhizobium meliloti isolates based on REP and ERIC-PCR amplification patterns, and it ranged from 35 to $100 \%$.

The dendrogram also showed that the isolates were clustered into two groups branching at a similarity of $35 \%$ the first major group contained one isolate Bs16 which was drought and salt moderate tolerant and low /high temperature tolerant(previous work) (Hameed, Hussain, \& Aljibouri, 2014).

The second major group included the rest of isolates, which splits into two subgroups with $68 \%$ similarity, the first subgroup comprised all sensitive isolates with $80 \%$ similarity between them. The second subgroup included the tolerant and moderate isolates with $88 \%$ similarity between them.

The dendrogram also showed that the isolates Bs31, 41, 30 and Bs38 were identical. The results showed that REP and ERIC-PCR indicate the efficiency and usefulness of using this technique in differentiation between Sinorhizobium meliloti isolates, and that the outcome obtained have was more corresponding to the results gained based on phenotypic characterization tests(previous work) (Hameed et al., 2014). These results shows that ERIC fingerprinting had a great discriminatory power which could be used for diversity analysis and species identification, and this is agreed with Aguilar, Lopez, and Riccillo (2001) and Metha et al. (2006).

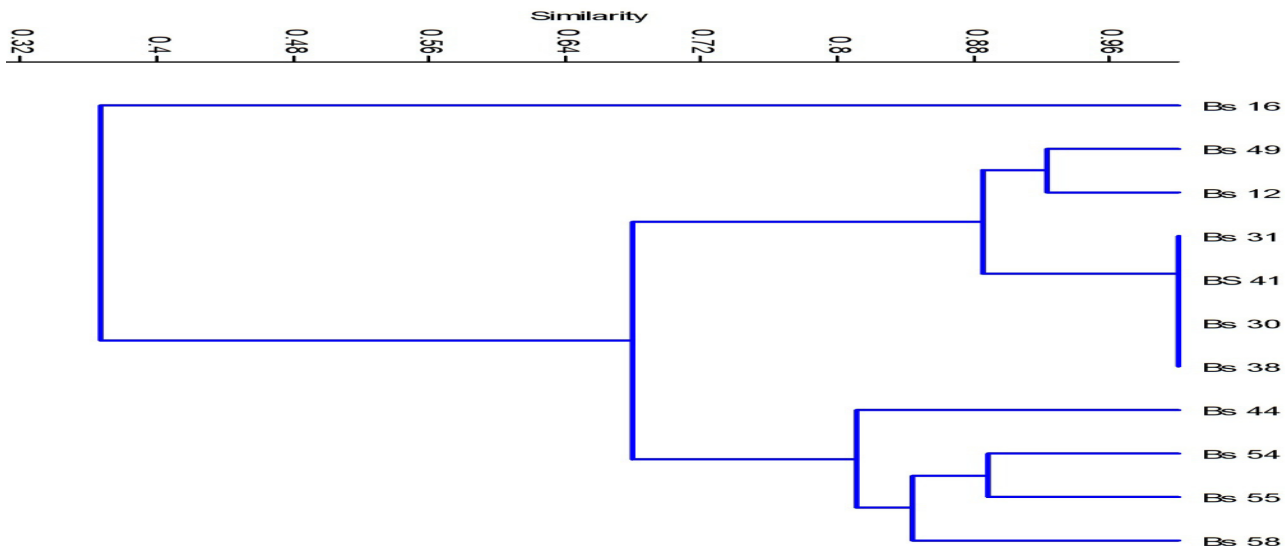

Figure 4. Dendrogram of Sinorhizobium meliloti isolates derived from rep-PCR fingerprints generated using REP and ERIC primers

\section{References}

Aguilar, O., Lopez, M., \& Riccillo, P. (2001). The diversity of rhizobia nodulating beans in Northwest Argentina as a source of more efficient inoculant strains. J. of Biotechnology, 91, 181-188.

Bremer, E., \& Kramer, R. (2000). Coping with osmotic challenges: osmoregulation through accumulation and release of compatible solutes in bacteria, In G. storz \& R. Hengge-Aronis (ed.), Bacterial Stress Response (pp. 79-97).

De-Bruijin, F. (1992). Use of repetitive (repetitive extragenic palindromic and enterobacterial repetitive intergenic consenus) sequences and the polymerase chain reaction to fingerprint the genomes of Rhizobium meliloti isolates and other soil bacteria. Appl. Environ. Microbiol, 58, 2180-2187.

Elboutahiri, N., Hami Alami, I., \& Udupa, S. (2010). Phenotypic and genetic diversity in Sinorhizobium meliloti and $S$. medicae from drought and salt affected regions of morocco, BMC Microbiology, Open access Res. Retrieved from http://www.Biomedcentral.com/1471-2180/10/15

Gao, J., Terefework, Z., Chen, W., \& Lindstorm, K. (2001). Genetic diversity of rhizobia isolated from Astragalus adsurgens growing in different geographical regions of china. J. Biotechnol, 91, 155-168.

Hameed, A., Hussain N., \& Aljabouri, M. (2014). Phenotypic characterization of indigenous Iraqi Sinorhizobium meliloti isolates for a biotic stress performance. J. of Life Sciences, 8(1), 1-9.

Hossein, A., \& Leila, M. (2010). Assessing tolerance of rhizobial lentil symbiosis isolates to salinity and drought in dry forming condition. In World Congress of Soil Science, Soil Solution for a Changing World, Brisbane, Australia, 13-16. 
Lisek, A., Paszt, L., Oskiera, M., Kulisiewicz, A., \& Malusa, E. (2011). Use of the rep-PCR technique for differentiating isolates of rhizobacteria. J. of Fruit and Ornamental Plant Research, 19(1), 5-12.

Metha, A., Metha, R., \& Rosato, B. (2006). ERIC and REP-PCR amplify non-repetitive fragments from the genome of Drechslera avehae and Stemphylium solani, $5^{\text {th }}$ congress of European Microbiologists, 211(1), $51-55$.

Pereira, S., Lima, A., \& Figueira, E. (2008). Rhizobium leguminosarium isolated from agricultural ecosystems subjected to different climatic influences: The relation between genetic diversity salt tolerance and nodulation efficiency. In T.-X. Liu (Ed.), Soil Ecology Research Developments (pp. 247-263). Nova Science Publisher, Inc., New York.

Raja, P., Balachandar, D., \& Sundaram, S. (2008). PCR fingerprinting for identification and discrimination of plant-associated facultative methylobacteria. Indian journal of Biotechnology, 7, 508-514.

Roy, R., Mazumder, P., \& Sarma, G. (2009). Prolin, protein, catalase and root traits as indices of drought resistance in bold grained rice (Oryza sativa) genotypes. African J. of Biotechnology, 8(23), 652-658.

Sikora, S., \& Redzepovic, S. (2003). Genotypic characterization of indigenous Soybean rhizobia by PCR-RFLP of 16S-Rdna, rep-PCR and RAPD analysis. Food technol. Biotechnol., 41(1) 61-67.

Tara, M. (2016). Iraq country pasture/forage resource profile online link. Retrieved from http://www.fao.org/ay/ doc/Iraq.html

Turner, N., Wright, G., \& Siddique, K. (2001). Adaptation of grain legumes(pulses) to water limited environments. Advances in Agronomy, 71, 193-231.

Versalovic, J., Schneider, M., De-Bruijin, F., \& Lupski, J. (1994). Genomic fingerprinting of bacteria using repetitive sequence based on polymerase chain reaction methods. Mol. Cellular Biol., 5, 25-40.

Vincent, J. (1970). Amanual for the practical study of the root-nodule bacteria. IBP Handbook No. 15. Blackwell, Oxford, UK.

Zahran, H. (1999). Rhizobium-legume symbiosis and nitrogen fixation under sever conditions and in arid climate. Microbial Mol. Biol. Rev., 63, 968-989.

Zeng, Z., Chen, W., Hu, Y., Su, X., \& Chen, D. (2007). Screening of highly effective Sinorhizobium meliloti strains for "rector" alfalfa and testing of its competitive nodulating ability in the field. Pedosphere, 17, 219-228.

\section{Copyrights}

Copyright for this article is retained by the author(s), with first publication rights granted to the journal.

This is an open-access article distributed under the terms and conditions of the Creative Commons Attribution license (http://creativecommons.org/licenses/by/3.0/). 